\title{
Między Bawarią a Prusami Wschodnimi Związki geograficzne, historyczne i kulturowe a współczesne postrzeganie dziedzictwa ziem pruskich
}

\begin{abstract}
Zarys treści: Dzisiejsza Bawaria, najbogatszy land współczesnych Niemiec, składa się m.in. z historycznych ziem Frankonii i Szwabii. Prusy Wschodnie już nie istnieją, ale pamięć o nich jest wciąż żywa wśród dawnych mieszkańców, którzy zostali celowo wysiedleni lub wyjechali samodzielnie po II wojnie światowej. W rozdziale wskażę na podobieństwa i różnice w położeniu geograficznym oraz na związki historyczne i kulturowe na przestrzeni wieków. W drugiej części rozdziału zatrzymam się na prezentacji dziedzictwa ziem pruskich przez Centrum Kultury Prus Wschodnich w Ellingen, mieszczącym się w dawnym pałacu Zakonu Niemieckiego (w Polsce zwanego Krzyżackim) w centralnej części Bawarii. Sześciotygodniowy staż naukowy w Ellingen pozwolił mi na osobiste spostrzeżenia, które wzbogacą wiedzę pozyskaną z polskich i niemieckich źródeł i literatury naukowej.
\end{abstract}

Słowa kluczowe: Bawaria, Prusy Wschodnie, dziedzictwo kulturowe, Centrum Kultury Prus Wschodnich.

\section{Wprowadzenie}

Wyjeżdżając na jesieni 2019 roku na staż naukowy do Bawarii ${ }^{1}$, nie zdawałam sobie sprawy ani z różnic, ani tym bardziej z podobieństw, które dzielą lub łączą ten niemiecki land z Warmią i Mazurami. Przebywając sześć tygodni we Frankonii i odbywając krótkie podróże po innych częściach Bawarii zaczęłam dostrzegać to, co dzieli i co łączy oba regiony. Pracując w Centrum Kultury Prus Wschodnich (Kulturzentrum Ostpreussen) w Ellingen, mieszczącym się w byłej rezydencji zakonu krzyżackiego, coraz bardziej odkrywałam elementy wspólne, o których w ogóle nie mówi się w Polsce. Od lat 90. pracuję naukowo na Uniwersytecie Warmińsko-Mazurskim, a od kilku lat głębiej zajmuję się dziedzictwem regionu, jednak w żadnej pracy naukowej nie znalazłam wzmianek o związkach

${ }^{1}$ Program Rozwojowy Uniwersytetu Warmińsko-Mazurskiego w Olsztynie współfinansowany przez Unię Europejską w ramach Europejskiego Funduszu Społecznego - Program Operacyjny Wiedza Edukacja Rozwój, POWR.03.05.00-00-Z310/17. 
historycznych ani kulturowych Warmii i Mazur (szerzej ziem pruskich) z Bawarią. Zaskoczeniem dla mnie był fakt, iż z ponad 30 wielkich mistrzów Zakonu w Prusach, połowa była pochodzenia południowo-niemieckiego. Co prawda w literaturze naukowej podaje się, którzy z wielkich mistrzów krzyżackich wywodzili się z konkretnego miasta niemieckiego, jednak bez wskazania na region, w którym to miasto się znajduje. Przy omawianiu rodu Hohenzollernów wymienia się ich posiadłości w Niemczech, ale bez podawania konkretnych przykładów współpracy bawarsko-wschodniopruskiej. To wszystko skłoniło mnie do próby systematyzacji tego zagadnienia i ukazania związków geograficznych, historycznych i kulturowych w ciągu wieków, a jednocześnie zwrócenia uwagi na współczesne postrzeganie dziedzictwa kulturowego ziem pruskich poprzez zbiory i wystawy organizowane przez Centrum Kultury Prus Wschodnich w Ellingen.

Głównym źródłem informacji, oprócz obserwacji i badań terenowych, były dla mnie materiały (źródła historyczne, literatura i ikonografia) przygotowane przez Centrum Kultury do wystawy gabinetowej w języku niemieckim nt. „Frankonia w Prusach. Prusacy we Frankonii. Historyczne i kulturowe interakcje w ciągu ośmiu wieków" prezentowanej w 2010 roku. Najbardziej znaną osobistością, o której uczą się już dzieci w szkole podstawowej, był ostatni Wielki Mistrz Zakonu Krzyżackiego, a pierwszy książę pruski w Królewcu, Albrecht Hohenzollern z Ansbach (leżącym w regionie Frankonii). Frankończycy początkowo przyczynili się do budowy potęgi Zakonu w Prusach, budowy zamku w Malborku i przeniesienia swojej stolicy do Prus. Wymienić tu można m.in. pierwszych wielkich mistrzów: Siegfrieda von Feuchtwangen (Feuchtwangen - Malbork) oraz jego brata Konrada (Hohenloher Land - Malbork). Znacząca jest ich rola we wprowadzeniu reformacji: reformator Andreas Osiander (Gunzenhausen - Królewiec) czy teolog Paul Speratus (Würzburg - Kwidzyn).

Mimo że książek o Mikołaju Koperniku powstało w Polsce bardzo dużo, jednak mało kto uświadamia sobie, że drukował on swoje dzieło De revolutionibus orbium coelestium libri VI właśnie we Frankonii, w Norymberdze, bowiem w XVI wieku była ona wolnym miastem i prężnym ośrodkiem drukarskim. Widoczne są także inne związki między Norymbergą a biskupią Warmią, co odkryłam dopiero po powrocie ze stażu, w listopadzie 2019 roku, zwiedzając Muzeum Archidiecezji Warmińskiej w Olsztynie ${ }^{2}$. Otóż eksponowane są tam mosiężne misy z XV-XVI wieku wykonane w Norymberdze dla Braniewa. Odnotować też warto, iż matka Immanuela Kanta pochodziła również z Norymbergii.

W XIX i XX wieku ziemie pruskie wydały bardzo cenionych artystów i naukowców, którzy następnie pracowali także w Bawarii, takich jak Ernst Theodor Amadeus Hoffmann (Królewiec - Bamberg), laureat Nagrody Nobla z fizyki Wilhelm Wien (Kętrzyn - Würzburg), chirurg Johann von Dieffenbach (Królewiec

\footnotetext{
${ }^{2}$ http://archwarmia.pl
} 
- Würzburg). Tak więc Frankonia (a szerzej Bawaria) i Prusy mają bliskie stosunki, które do dziś są aktualne dzięki opiece kulturalnej i finansowej Wolnego Państwa Bawarskiego dla Wspólnoty Krajowej Prus Wschodnich oraz siedziby wielu wspólnot powiatowych i miejskich $\mathrm{z}$ dawnych Prus Wschodnich na terenie całej Bawarii.

\section{Związki geograficzne}

To, co najbardziej jest widoczne w porównaniu Bawarii i południowej części Prus Wschodnich (dzisiejszych Warmii i Mazur), to zieleń lasów i błękit wód (rzek i jezior). Czyste powietrze, liczne szlaki turystyczne, tradycyjna zabudowa wsi, to elementy wspólne. Natomiast północna część Prus Wschodnich (dzisiejszy Obwód Kaliningradzki) jest całkowitym zaprzeczeniem południowej Bawarii. Wysokie Alpy kontrastują z Mierzeją Kurońską i równinami regionu kaliningradzkiego. Jedynie widoki na bezkresne morze rozpościerające się ze skalistego nabrzeża Półwyspu Sambijskiego porównywać można do pejzaży rozpościerających się z alpejskich gór (Dudo 1995: 22-25) (ryc. 1).

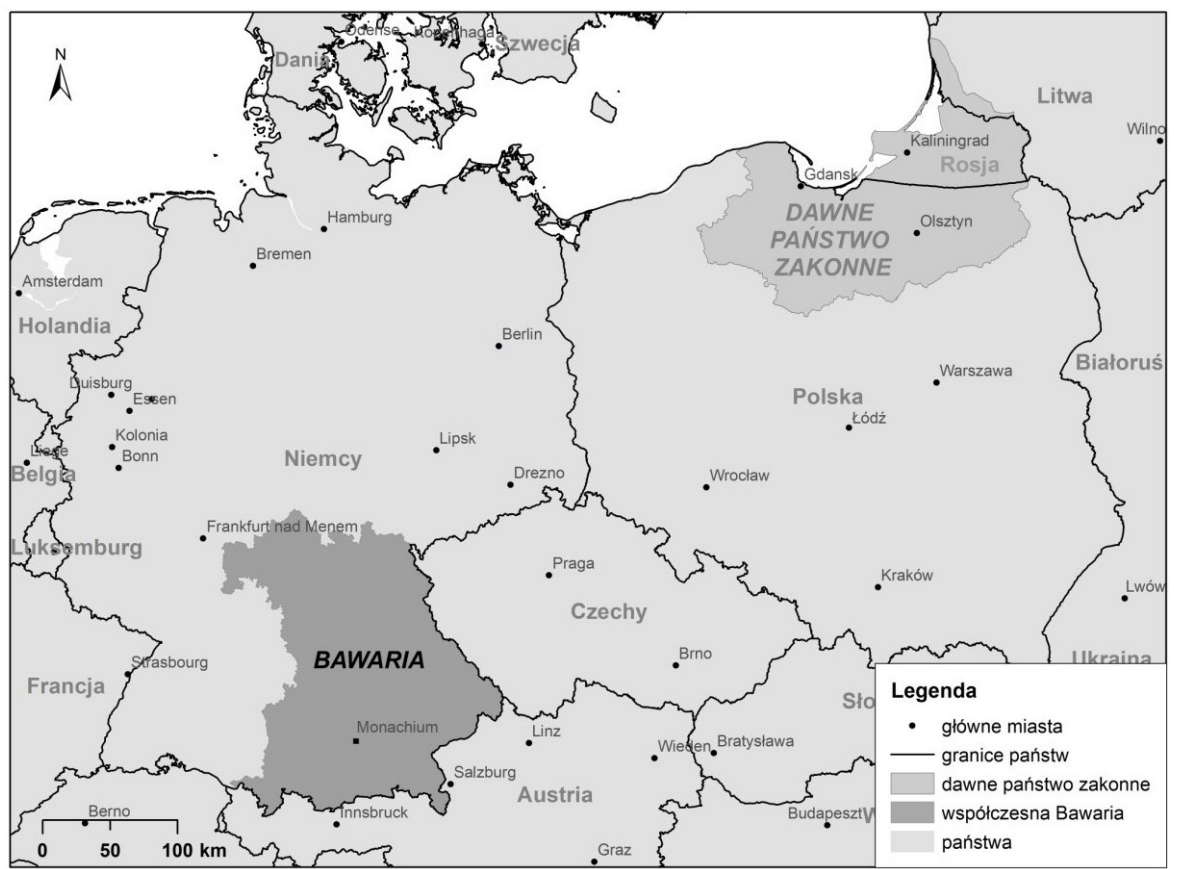

Ryc. 1. Położenie obecnej Bawarii i dawnego państwa zakonnego na mapie Europy Środkowo-Wschodniej 
Bawaria jest największym z niemieckich landów. Historycznie dzieli się na Bawarię zwaną czasami „właściwą” lub „starą”, Frankonię oraz Szwabię. Administracyjnie na Dolną Frankonię (Würzburg), Górną Frankonię (Bayreuth), Środkową Frankonię (Ansbach), Szwabię (Augsburg), Górny Palatynat (Ratyzbona), Górną Bawarię (Monachium) oraz Dolną Bawarię (Landshut). Od wschodu land sąsiaduje z Czechami oraz Austrią, która jest też sąsiadem Bawarii od południa. Od zachodu graniczy z innym landem niemieckim Badenią-Wirtemberią. Od północy z kolei z Hesją, Turyngią oraz, na niewielkim odcinku, z Saksonią. Bawaria zajmuje powierzchnię ponad $70551 \mathrm{~km}^{2}$, zamieszkuje ją łącznie blisko $12,8 \mathrm{mln}$ osób (Kłopotowski 2018: 28).

Prusy Wschodnie jako odrębny kraj Rzeszy Niemieckiej zostały rozwiązane decyzją trzech mocarstw w 1947 roku. Co prawda decyzje przejęcia tego terenu przez Polskę i Związek Radziecki zapadły na konferencji w Jałcie, ale nazwa Prus przestała istnieć dopiero dwa lata po zakończeniu II wojny światowej. Obecnie to obszar podzielony na trzy kraje - Polskę, Rosję i Litwę (Lewandowska 2009: 241-249). Południowa część dawnych Prus Wschodnich przypadła Polsce i tworzy administracyjny region: województwo warmińsko-mazurskie. Jest ono czwartym co do wielkości województwem Polski o powierzchni około $24173 \mathrm{~km}^{2}$. Stolicą regionu jest Olsztyn (ok. 173000 mieszkańców). Inne duże miasta to: Elbląg (130000) i Ełk (61500).

Obwód Kaliningradzki (wcześniej środkowa część Prus Wschodnich) to eksklawa Rosji otoczona ziemiami litewskimi i polskimi, ze stolicą w Kaliningradzie (niem. Königsberg, pol. Królewiec). Ta najbardziej wysunięta na zachód część Federacji Rosyjskiej jest odizolowana od głównej części kraju i otoczona obcym terytorium od czasu upadku Związku Radzieckiego w 1991 roku. Ponadto polityczne aspekty izolacji regionu stały się wyraźne, gdy tylko Litwa i Polska przystąpiły do Unii Europejskiej. Kaliningrad to nie tylko kwatera główna rosyjskiej floty bałtyckiej, ale także najbardziej zmilitaryzowany obszar Federacji Rosyjskiej. Liczba instalacji wojskowych znajdujących się w Obwodzie jest najwyższa w Europie.

Region Kłajpedy (wcześniej północno-wschodnia część Prus Wschodnich) jest obecnie nazywany Krajem Rzeki Niemen. Kłajpeda oznacza po niemiecku „Memel”, co po polsku znaczny Niemen. Dzisiejszy region Kłajpedy obejmuje dawne ziemie staropruskie, zwane potem Małą Litwą lub Litwą Mniejszą (ta część należała do Prus Wschodnich), ale także ziemie należące do historycznej Żmudzi, które miały więcej połączeń z Polską niż z Niemcami czy Prusami Wschodnimi. Kłajpeda jest dogodnie położona u ujścia rzeki Dangi do Zalewu Kurońskiego, połączonej kanałem z ujściem rzeki Niemen, wpadającej do Morza Bałtyckiego. Po II wojnie światowej zbudowano tam gigantyczną stocznię i port rybacki. Obecnie Kłajpeda jest jedynym portem na Litwie, który umożliwia po- 
dróż promem do Szwecji i Niemiec. W pobliżu Kłajpedy znajdują się co najmniej dwa powszechnie cenione kurorty nadmorskie, tj. Nida na południu na Mierzei Kurońskiej i Połąga na północy.

Krajobraz Bawarii dzieli się na cztery główne regiony: 1) Alpy Bawarskie ze szczytem Zugspitze (2962 m n.p.m.); 2) Przedgórze Alpejskie z licznymi jeziorami; 3) Średniogórze Wschodniobawarskie z pierwszym w Niemczech parkiem narodowym; 4) Progi Szwabsko-Frankońskie. Konserwacja przyrody i ochrona środowiska są bardzo ważne i są integralną częścią konstytucji bawarskiej od 1984 roku. Niemieckie Stowarzyszenie Alpejskie (Deutscher Alpenverein) postawiło sobie za zadanie udostępnienie Alp turystom jednocześnie konserwując alpejską przyrodę.

Środowisko wodne Bawarii to m.in. dwie główne rzeki przepływające przez land - Dunaj i Men. Nad Dunajem leżą duże miasta, jak Pasawa, Ratyzbona i Ingolstadt. Jego dopływy to: Izara (przecina Monachium) oraz rzeka Inn (uchodzi do Dunaju w Pasawie). Jeszcze inną rzeką jest Lech przepływająca m.in. przez Augsburg oraz Landsberg. Na północy landu liczne zakola tworzy Men. W regionie nie brakuje jezior górskich. Najważniejsze z nich to Chiemsee na wschodzie, Stamberger See oraz Ammersee w regionie Monachium, położone w Alpach Bawarskich Kochelsee, Walchensee oraz Tegernsee, a także Bodensee (Jezioro Bodeńskie), którego wschodni kraniec należy do Bawarii (McLachlan 1998: 103-120).

Region Warmii i Mazur określany jako „kraina tysiąca jezior” uznawany jest za jeden z najpiękniejszych obszarów Polski. Wody obejmują 5\% powierzchni województwa, a lasy ponad 30\%. Wielkie Jeziora Mazurskie położone są w rejonie między Węgorzewem, Giżyckiem, Mikołajkami i Rynem. Mazurski Park Krajobrazowy powstał w 1977 roku, podobnie jak Park Przyrody rzeki Altmühltal utworzony w 1979 roku w środkowej Frankonii. Walory przyrodnicze obu regionów (jeziora, rzeki, unikalna fauna i flora) przyciągają rzesze turystów. Niemniej województwo warmińsko-mazurskie jest jednym z najmniej rozwiniętych gospodarczo obszarów w Polsce.

Na obszarze Warmii i Mazur, Obwodu Kaliningradzkiego i regionu Kłajpedy mamy zróżnicowany stan rozwoju ekonomicznego. Gospodarka dawnych Prus Wschodnich to przede wszystkim rolnictwo i rybołówstwo. W miastach nadmorskich i związanych z wodą rozwija się przemysł stoczniowy (Kaliningrad, Kłajpeda, Elbląg, Giżycko, Ostróda). Dostępność surowca stwarza możliwości rozwoju przemysłu drzewnego i meblarskiego. Norymberga i Monachium są ważnymi ośrodkami targowymi - odbywają się tu międzynarodowe targi budowlane, turystyczne, maszynowe. Kwitnie też turystyka. Bawaria należy do najpopularniejszych celów wycieczek w Niemczech. Podobnie Warmia i Mazury, jak również nadmorskie miejscowości Obwodu Kaliningradzkiego, Mierzei Kurońskiej i Kłajpedy (Dudo 1995: 112-118). 
Bawaria kojarzy się głównie z przemysłem motoryzacyjnym. Najbardziej rozpoznawalną marką są produkowane w Monachium samochody i motocykle firmy BMW (Bayerische Motoren-Werke, czyli Bawarska Fabryka Silników). Inną popularną marką jest AUDI z siedzibą w Ingolstadt. Trzecia z marek to MAN (Maschinenfabrik Augsburg-Nürnberg), która produkuje głównie autobusy i samochody. Z Bawarią związane są też takie firmy, jak Siemens, Airbus i Allianz (Kłopotowski 2018: 31). Najbardziej prosperującymi gałęziami przemysłu w Kaliningradzie są firmy produkujące samochody i ciężarówki oraz ich części, np. GM, BMW, KIA. Rybołówstwo jest również jedną z najważniejszych gałęzi przemysłu $\mathrm{w}$ tym regionie, $\mathrm{z}$ rozległymi portami rybackimi w Kaliningradzie i Pionerskij. Kaliningrad to port morski i centrum administracyjne.

Ludność obu regionów jest zróżnicowana etnicznie i kulturowo, co uwidacznia się w kuchni regionalnej, dialektach, kultywowanych zwyczajach. Na 12,8 mln mieszkańców Bawarii najwięcej jest rodowitych Bawarczyków - 6,4 mln osób, Frankowie to 4,1 mln osób, zaś Szwabowie - 1,8 mln osób. Pozostali to tzw. nowi Bawarczycy, czyli ci, który przybyli do landu po II wojnie światowej oraz współcześni uchodźcy (Ibidem, s. 32).

Województwo warmińsko-mazurskie liczy 1,4 miliona mieszkańców (60 osób na $\mathrm{km}^{2}$ ). To region najbardziej zróżnicowany etnicznie w Polsce. Mniejszości narodowe to Ukraińcy $(6,6 \%)$, Niemcy $(1,6 \%)$ i Białorusini $(0,2 \%)$. Mniejszości etniczne to Mazurzy, Warmiacy, Romowie i Łemkowie. Według danych z 2015 r. w Kaliningradzie mieszkało 453500 obywateli. Cały obwód zamieszkiwany był przez 955000 mieszkańców, z czego $78 \%$ to mieszkańcy miast, a 22\% wsi. Obwód Kaliningradzki, z 62,5 osobami na kilometr kwadratowy,jest czwartym najbardziej zaludnionym obszarem w Federacji Rosyjskiej. Stał się mieszanką narodowościową po II wojnie światowej. Rodowici Niemcy uciekli lub zostali przesiedleni, a ich miejsce zajęli przede wszystkim Rosjanie (dzisiaj to 86\% mieszkańców), ale też inne narodowości, jak Białorusini (5,3\%), Ukraińcy (4,9\%), Litwini (1,4\%), Ormianie $(0,9 \%)$, Tatarzy $(0,5 \%)$, Polacy $(0,4 \%)$ i inni. Wymienia się ponad 25 mniejszości narodowych i etnicznych. Szeroko te problemy omawia Andrzej Sakson wskazując na trudną identyfikację narodowościową mieszkańców Obwodu (Sakson 2011: 409-563). Trzecia z części dawnych Prus Wschodnich, czyli Okręg Kłajpedy ma powierzchnię 5209 km² i liczy ponad 337000 mieszkańców. Liczba mieszkańców stolicy wynosi 187350 . Według najnowszych danych struktura etniczna przedstawia się następująco: 85,2\% Litwinów, 11,6\% Rosjan, 1,3\% Ukraińców, 1\% Białorusinów, 0,3\% Polaków, pozostali to Łotysze, Żydzi, Tatarzy i Romowie. Po II wojnie światowej zaczęli żyć razem: 1) starzy tubylcy Litwy Mniejszej - Litwini, Kurończycy i Niemcy z Prus; 2) osadnicy litewscy, którzy przybyli ze Żmudzi i środkowej Litwy; 3) Rosjanie i inne grupy etniczne pochodzące ze Związku Radzieckiego. W ostatnich latach struktura narodowościowa zmienia się na korzyść Litwinów (Ibidem, s. 361-408). 


\section{Związki historyczne w średniowieczu}

Związki historyczne między Frankonią a ziemiami pruskimi w XIII-XVI wieku początkowo były związane z panowaniem zakonu krzyżackiego, którego kilku wielkich mistrzów pochodziło z Frankonii. Kiedy w 1808 roku Frankonia została włączona do Bawarii można mówić o związkach między tym regionem a ówczesnymi Prusami Wschodnimi (Arnold, Seis, Freyberg 2016: 62).

Pierwszym Wielkim Mistrzem Zakonu Krzyżackiego, pionierem chrystianizacji plemion pruskich, był Konrad von Feuchtwangen (przed 1230-1296) (Feuchtwangen - Elbląg) (AKZO; Piuziński 2003: 55-59). Pochodził z frankońskiej rodziny ministerialnej, która miała siedzibę w cesarskim opactwie Feuchtwangen. Do czasu przybycia do Prus był komturem krajowym w Baliwacie Austria ${ }^{3}$, skarbnikiem Zakonu w Ziemi Świętej, doradcą politycznym króla Rudolfa Habsburga. W 1279 roku został wybrany przez Kapitułę Zakonu Landmistrzem Prus i Inflant. Potem przeniósł się do swojego rodzinnego Baliwatu Frankonii, gdzie został mianowany komturem krajowym w latach 1282 i 1284. Jako mistrz krajowy wykorzystał swoje dobre stosunki z niemieckimi domami książęcymi, zwiększył znaczenie Zakonu i poprawił stosunki z Prusami, co sprzyjało powstaniu państwa zakonnego na Wschodzie. W 1291 roku został wybrany przez kapitułę generalną na wielkiego mistrza i przeniósł do Wenecji swoją siedzibę. Jednocześnie zajął się administracją ziem pruskich - uchwalił nowe prawo w celu zapewnienia porządku, założył nowe obiekty handlowe i miasta. Podkreślając duszpasterskie i charytatywne zadania Zakonu dążył do stworzenia własnego państwa religijnego. Kilkakrotnie jeździł do Prus, a w 1296 roku został zaprzysiężony przez kapitułę generalną w Elblągu. W drodze powrotnej z Prus do Wenecji Konrad von Feuchtwangen zmarł w niemieckim zakonie Drobowitz w Czechach. Jego kości zostały pochowane w lokalnej katedrze.

Kolejnym Wielkim Mistrzem Zakonu Krzyżackiego pochodzącym z Frankonii był Siegfried von Feuchtwangen (przed 1273-1311), (Feuchtwangen - Malbork) (AKZO; Piuziński 2003: 64-68). W dokumentach po raz pierwszy pojawił się w 1298 roku w sporze między nim jako mistrzem Zakonu Niemieckiego a innymi braćmi. W tym samym czasie rozpoczęła się walka o władzę między Zakonem, królem Francji Filipem IV i papiestwem. W 1303 roku w Elblągu odbyły się kontrowersyjne wybory Siegfrieda von Feuchtwangena na nowego mistrza Zakonu. Tylko władcy Prus i Inflant potwierdzili ten wybór, w Niemczech nie został uznany. Dzięki umiejętnościom dyplomatycznym Siegfried był w stanie zwyciężyć partię dotychczasowego wielkiego mistrza Gottfrieda von Hohenlohe i zapobiec podziałowi Zakonu. Jednak dopiero kiedy Gottfried zmarł

\footnotetext{
${ }^{3}$ Baliwaty (prowincje), to terenowe struktury władzy, które dzieliły się na komendy (komturie).
} 
w Marburgu w 1309 roku, jego następca mógł objąć ten zaszczytny urząd. W polityce zagranicznej spotkał potężnego przeciwnika, arcybiskupa Rygi, który opowiedział się po stronie pogańskich Litwinów przeciwko dalszej ekspansji Zakonu. W końcu Zakon zaatakował litewską armię i przejął posiadłości Rygi w Kurlandii. Arcybiskup przeszedł na emeryturę do Rzymu i złożył skargę do kurii papieskiej przeciwko Zakonowi. Papież pod wpływem Francji zajął w 1309 roku Wenecję z dotychczasową siedzibą Zakonu Niemieckiego. Wobec tego Siegfried podjął decyzję przeniesienia głównego domu zakonnego do Malborka, zgodnie z planem swojego poprzednika Konrada von Feuchtwangena. W ten sposób ostatecznie zdecydował o politycznej reorientacji Zakonu na obszar Prus. W ciągu swojego panowania zwiększył potęgę gospodarczą kraju, poszerzył i skonsolidował obszar Zakonu, zdobywając Gdańsk i Pomorze, zapewnił nowym granicom ważny system obronny w postaci sieci zamków (ryc. 2).

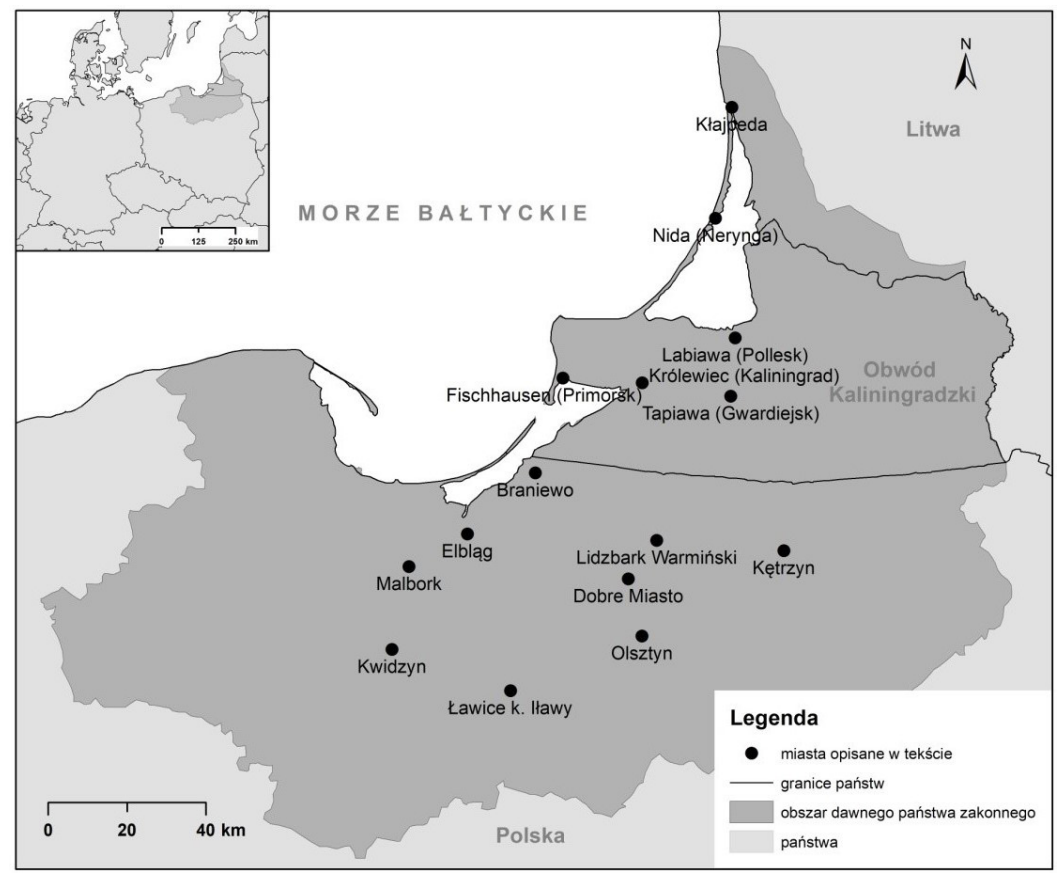

Ryc. 2. Dawne państwo zakonu krzyżackiego w Prusach Źródło: oprac. Ł. Musiaka

Ponad sto lat trzeba było czekać na następnego Wielkiego Mistrza Zakonu Krzyżackiego, który pochodził ze szwabsko-frankońskiej rodziny ministerialnej, panów Hohenlohe. Był nim Konrad von Erlichshausen (1390/1395-1449), (Malbork) (AKZO; Piuziński 2003: 144-149). Zanim został wybrany wielkim mistrzem w 1441 roku, sprawował kilka funkcji religijnych i wojskowych w Rog- 
genhausen (pol. Rogóż), Ragnit (ros. Neman), Toruniu i Chełmnie. Przez dziesięć lat był Wielkim Komturem i Marszałkiem Zakonu. Kiedy objął urząd, zaczęły się problemy z powstałym w 1440 roku Związkiem Pruskim. Była to federacja miast pruskich i mieszkańców wsi, którzy chcieli odeprzeć wszelką ingerencję Zakonu w ich prawa i wolności. Początkowo udało się rozwiązać spory, a stosunki z Polską za nowego króla Kazimierza IV poprawiły się, dlatego w 1448 roku w Kętrzynie zawarto traktat pokojowy. Konrad von Erlichshausen zmarł rok później w Malborku i tam został pochowany.

Kuzynem Konrada von Erlichshausena, pochodzącym z tej samej szwabsko-frankońskiej rodziny ministerialnej, był Ludwig von Erlichshausen (1415-1467), Wielki Mistrz Zakonu Niemieckiego (Crailsheim - Malbork - Królewiec) (AKZO; Piuziński 2003: 150-156). W 1434 roku wstąpił do Zakonu jako adiutant komtura Brandenburgii. Przez kilka lat stopniowo awansował, zanim został wybrany wielkim mistrzem w 1450 roku. Najważniejszym wydarzeniem za jego rządów były konflikty ze Związkiem Pruskim, które doprowadziły do wojny trzynastoletniej. We wrześniu 1454 roku doszło do pierwszego dużego starcia w bitwie pod Chojnicami, w której strona polska poniosła klęskę. Jednak wielki mistrz Ludwig nie zdołał odwrócić losów Zakonu. Prestiżowy zamek w Malborku został przyrzeczony zwerbowanym, ale nieopłaconym najemnikom. Ci zaś sprzedali zamek królowi polskiemu. W 1457 roku wielki mistrz musiał opuścić stolicę w Malborku i potajemnie uciekł do Królewca. 19 października 1466 roku pokój w Toruniu zakończył ostatecznie wojnę. Pokój mocno uderzył w państwo zakonne, oprócz wysokich kosztów wojennych 5,7 miliona węgierskich guldenów, Zakon musiał zaakceptować duże straty terytorialne. Dotyczyły one Pomorza i ziemi chełmińskiej, a także obszarów Gdańska, Elbląga, Malborka, Sztumu, Dzierzgonia i Torunia. Prusy Zachodnie zostały podporządkowane polskiej Koronie pod nazwą Prus Królewskich, a biskupia Warmia, jako księstwo z dużą autonomią, należało teraz do państwa polskiego. Po negocjacjach pokojowych Ludwig von Erlichshausen powrócił do swojej nowej rezydencji w Królewcu, gdzie zmarł pół roku później. Jego kości pochowano w tamtejszej katedrze.

\section{Okres nowożytny - więzi historyczne i kulturowe}

Najbardziej rozpoznawalnym przez polskie społeczeństwo (poza Ulrichem von Jungingenem, który zginął w bitwie pod Grunwaldem) jest Albrecht Hohenzollern (1490-1568), margrabia Brandenburgii-Ansbach, ostatni mistrz zakonu krzyżackiego, pierwszy książę w Prusach (Ansbach - Królewiec) (AKZO; Piuziński 2003: 184-190). Urodził się 17 maja 1490 roku jako syn margrabiego Ansbachu Fryderyka i jego żony Zofii, polskiej księżniczki, córki króla Zygmunta Starego. Albrecht otrzymał wykształcenie kanoniczne. Przeznaczono go do kariery duchownej, gdyż jego dwaj starsi bracia, Kazimierz i Jerzy, podzielili się ojcowskimi 
ziemiami. Kiedy wielki mistrz Zakonu Fryderyk Saksoński zmarł w 1510 roku, dla Albrechta otworzyła się szansa zostania jego następcą. Ze względu na swoje powiązania rodzinne z polską rodziną królewską nadawał się jak nikt inny, aby stanąć na czele podzielonych ziem Zakonu w trudnym czasie po II pokoju toruńskim. Członkiem Zakonu został w 1511 roku mając zaledwie 21 lat. Jako nowy wielki mistrz, zarówno on i jak i jego poprzednik, odmówili złożenia przysięgi na wierność królowi polskiemu.

Kiedy Albrecht przebywał w latach 1522-1523 w Norymberdze, miał okazję wysłuchać kazań lokalnego reformatora Andreasa Osiandera, który zainspirował go do zmiany wyznania. W drodze powrotnej do Berlina spotkał się w Wittenberdze z Marcinem Lutrem, co dało mu impuls do rozwiązania zakonu religijnego i utworzenia państwa świecko-pruskiego oraz wprowadzenia reformacji w sensie protestanckim. Jego cele polityczne stały się rzeczywistością; w traktacie krakowskim z 9 kwietnia 1525 roku zakon krzyżacki został rozwiązany w Prusach i przekształcił się w dziedziczne księstwo pod zwierzchnictwem Polski. Tak więc Frankończyk został pierwszym księciem Prus. Z małżeństwa z Marią z Brunszwiku miał jedynego syna Albrechta Fryderyka, który okazał się dzieckiem niepełnosprawnym psychicznie. Albrecht Hohhenzollern zmarł w Tapiawie (ros. Gwardiejsk w Obwodzie Kaliningradzkim).

W XVI wieku jeszcze jeden z władców południowo-niemieckich był związany z ziemiami pruskimi. Był to Georg Friedrich Hohenzollern (1539-1603), margrabia Brandenburgii w Ansbach i Bayreuth, administrator Prus, (Ansbach - Królewiec) (AKZO). Urodził się jako jedyny syn margrabiego Georga z Brandenburgii-Ansbach i jego żony Zofii, księżnej Brunszwiku-Lüneburg. W 1556 roku po ojcu przejął panowanie w Ansbach, a wkrótce potem odziedziczył obszar Bayreuth. W ciągu prawie 18 lat zjednoczył w ręku Hohenzollernów wszystkie ziemie Frankonii. Dalszy wzrost władzy nastąpił w 1577 roku, kiedy został wyznaczony przez polskiego króla Zygmunta Augusta na opiekuna swego słabego kuzyna księcia Albrechta Fryderyka. Król polski powierzył mu wówczas zarząd administracji księstwa pruskiego. W marcu 1578 roku Georg Friedrich przeprowadził się ze swym frankońskim orszakiem szlachty i urzędników do Królewca. Cztery lata później jego frankoński dwór w Królewcu liczył 329 osób. Ponieważ w zamku prawie nie było miejsca, architekt margrabiów Blasius Berwart otrzymał zlecenie budowy nowego skrzydła zachodniego z zamkowym kościołem i dodatkową przestrzenią mieszkalną. W maju 1586 roku margrabia wrócił do Frankonii, jednak aż do śmierci w 1603 roku kontynuował regencję Prus z oddali. Okres administracji Georga Friedricha był dla Prus czasem rozwoju artystycznego i naukowego oraz stabilizacji gospodarczej, która nie odbyłaby się bez udziału ekspertów z południowej części Niemiec.

Najbardziej intensywne związki kulturalne między Frankonią/Bawarią a Prusami Książęcymi, a następnie Prusami Wschodnimi ujawniają się w dwóch 
okresach: $\mathrm{w}$ dobie reformacji (XVI w.) oraz w dobie rozwoju nauki i techniki (XIX i początek XX w.). Pierwszą osobą, która zasługuje na pamięć jest Andreas Hosemann, zwany Osiander (1498-1552), ojciec pruskiej reformacji (Gunzenhausen - Norymberga - Królewiec) (AKZO; Seebass 1967; Stupperich 1973). Andreas Osiander jest jednym z najważniejszych reformatorów pierwszej połowy XVI wieku. Miał decydujący wpływ na wprowadzenie wiary protestanckiej u margrabiów Ansbach i Kulmbach oraz w Palatynacie Reńskim. Urodził się w 1498 roku w Gunzenhausen we Frankonii jako syn kowala i radnego miejskiego. Po ukończeniu studiów w Lipsku i Altenburgu, Osiander studiował teologię na uniwersytecie w Ingolstadt. W 1520 roku otrzymał święcenia kapłańskie w Norymberdze i został nauczycielem języka hebrajskiego w klasztorze augustianów. Odprawiał także prywatne msze, by zarabiać na życie. Norymberga była w tym czasie bardzo otwarta na nową doktrynę Lutra i nowe idee. Osiander podążał za tymi poglądami i reformacją, a następnie został w 1522 roku mianowany pierwszym luterańskim kaznodzieją w głównych kościołach św. Wawrzyńca i św. Sebalda. W ciągu ponad 27 lat urzędowania stał się najpotężniejszym przedstawicielem reformacji w Norymberdze i uczestniczył w najważniejszych negocjacjach kościelnych.

Przy okazji wizyty w tym mieście w 1523 roku wielki mistrz Albrecht Hohenzollern usłyszał kazanie od elokwentnego Osiandera. Tak się rozpoczęła droga Albrechta do zmiany wyznania, które nastąpiło w 1525 roku. Przyjmuje się, że decyzja o sekularyzacji Zakonu została podjęta dzięki impulsom z Frankonii i Norymbergi, od Marcina Lutra, a także od Osiandera. Tego ostatniego Albrecht czcił jako swojego duchowego ojca i wezwał do Królewca w 1549 roku. Objął tam urząd pastora $\mathrm{w}$ kościele staromiejskim, a jednocześnie profesora teologii na uniwersytecie. W 1551 roku książę mianował go zarządcą biskupstwa Sambii. Tutaj otwarcie ujawnił się jego pogląd na usprawiedliwienie osoby przed Bogiem, któremu sprzeciwiali się inni profesorowie. Rozpoczął się spór teologiczny, w trakcie którego wielu profesorów i studentów z Królewca opuściło uniwersytet, a nawet zięć Osiandera, sądowy kaznodzieja Johann Funk, został stracony. W wyniku tych przejść reformator zmarł 17 października 1552 roku w Królewcu z powodu udaru mózgu. Został pochowany przed ołtarzem kościoła staromiejskiego. Jednak jego przeciwnicy nie pozostawili w spokoju jego doczesnych szczątków, wykopali jego ciało, a jego drugie miejsce pochówku nie jest do dzisiaj pewne. Należy też wspomnieć, że Osiander zajmował się również astronomią i matematyką, dlatego utrzymywał bliższe relacje z Mikołajem Kopernikiem, będącym przecież katolickim kanonikiem.

Innym ważnym teologiem i kaznodzieją czasów reformacji, określanym „Pruskim Orfeuszem”, był Johannes Graumann/Gramann, zwany Poliandrem (14861541) (Neustadt an der Aisch - Würzburg - Królewiec) (AKZO). Urodził się jako syn krawca w drugi dzień świąt Bożego Narodzenia 1486 roku. W wieku 17 lat 
został wysłany na najbliższy uniwersytet w Lipsku, w celu podjęcia studiów sztuk wyzwolonych. Stopień doktora otrzymał w 1516 roku i został przyjęty do pracy na wydziale filozofii. Poliander zaangażował się w spory doktrynalne i odwrócił się od kościoła rzymskiego. W latach 1523 i 1524 pracował jako kaznodzieja w Würzburgu. Kiedy książę Albert Hohenzollern dowiedział się o nim, mianował go staromiejskim pastorem Królewca. Pod wpływem tych samych poglądów teologicznych i frankońskiego pochodzenia rozwinęła się ścisła relacja między parą książęcą a Poliandrem. Książę Albrecht konsultował się z nim w ważnych sprawach szkolnych i kościelnych. Przeszedł do historii jako twórca różnych protestanckich hymnów i wierszy, które pomagały przy opracowywaniu zasad nowego pruskiego kościoła. Pieśni te są do dziś śpiewane w Kościele ewangelickim. Zasłużył się także jako twórca edukacji pruskiej, bowiem brał udział w budowie biblioteki zamkowej i Uniwersytetu Królewieckiego Albertina. Ostateczne miejsce spoczynku znalazł w staromiejskim kościele w Królewcu.

Pierwszym protestanckim biskupem Pomorza został znany w początkach XVI wieku teolog i kaznodzieja Paul Hoffer, zwany Speratusem (1484-1551) (Dinkelsbühl - Würzburg - Królewiec - Kwidzyn) (AKZO; Małłek 1987: 165-179). Od 1503 roku studiował we Fryburgu, Paryżu, Włoszech i Wiedniu. Uzyskał doktorat z filozofii, prawa i teologii. Po święceniach w 1506 roku był aktywny w kilku wspólnotach katolickich: Salzburgu, Dinkelsbühl i Würzburgu. Tam zapoznał się bliżej z doktryną Marcina Lutra, przeszedł na luteranizm i ożenił się z Anną Fuchs, przez co został zwolniony z obowiązków katolickich i musiał opuścić Würzburg. W katedrze św. Szczepana w Wiedniu 12 stycznia 1522 roku wygłosił sensacyjne kazanie o stanie cywilnym i ślubach zakonnych, po czym został ekskomunikowany przez wiedeński Wydział Teologiczny. Po pobycie w Iglau i Wittenberdze, gdzie przetłumaczył kilka łacińskich pism Lutra na niemiecki i promował publikację luterańskiej księgi hymnów, Speratus został w 1524 roku powołany przez księcia Albrechta do Królewca. W pałacu królewieckim otrzymał od księcia bezpłatne zakwaterowanie, pisał dzieła teologiczne, hymny uwielbienia i interpretacje Biblii. Wkrótce książę Albrecht i biskup Polenz zaangażowali go do odbudowy kościoła parafialnego w Prusach. W 1529 roku został wybrany pierwszym luterańskim biskupem Pomorza, w 1530 roku osiadł w Kwidzyniu, gdzie zmarł w 1551 roku.

Książę Albrecht Hohenzollern sprowadzał z południowych Niemiec na swój dwór w Królewcu nie tylko duchownych i kaznodziejów, ale także architektów i budowniczych, niezbędnych przy rozbudowie książęcego zamku oraz innych zamków w Prusach. Najsłynniejszym z nich był Blasius Berwart (1530-1589), (Ansbach - Plassenburg - Mergentheim - Królewiec) (AKZO; Bessau 1955: 173). Urodził się około 1530 roku w Leonberg jako syn kamieniarza i murarza. Ojciec pochodził ze starej szwabskiej rodziny artystów. Pracował przy budowie Tybingi, a później zamku w Stuttgarcie. W 1563 roku Berwart został poproszony przez 
księcia margrabiego Georga Friedricha z Ansbach i Bayreuth do udziału w rozbudowie zamku w Ansbachu. W tym samym czasie zlecono mu przebudowę Plassenburga pod Kulmbach, gdzie stworzył jeden z najpiękniejszych renesansowych dziedzińców na północ od Alp. Od 1571 roku kierował budową zamku krzyżackiego w Mergentheim, gdzie stworzył spiralne schody, które można podziwiać do dzisiaj. Kiedy jego władca Georg Friedrich przejął administrację Księstwa Pruskiego w 1577 roku, w zamku królewieckim utworzono drugi dwór frankijski. Wśród wielu urzędników, których książę zabrał do Królewca, był Blasius Berwart, który pracował tam przez dziewięć lat. Jego głównym dziełem była przebudowa zachodniego skrzydła zamku w Królewcu wraz z kościołem zamkowym. Ponadto w Prusach prowadził przebudowę zamków w Barcianach, Szczytnie, Morągu i Przezmarku. Po powrocie do Frankonii ponownie przejął zarządzanie budową pałacu w Ansbachu, a od 1588 roku zajął się rozbudową twierdzy Wülzburg koło Weißenburga.

Rok przed śmiercią pierwszego księcia pruskiego Albrechta Hohenzollerna, urodził się Sebastian Brotsorg, zwany Artomedesem (1544-1602), kolejny wielki poeta reformacji wywodzący się z Frankonii (Langenzenn - Ansbach - Królewiec) (AKZO; Gause 1953: 403). Pochodził z Langenzenn koło Norymbergi, studia teologiczne w Wittenberdze ukończył w 1567 roku. Początkowo był rektorem szkoły w Crailsheim, w 1572 roku został powołany do Ansbach jako kaznodzieja sądowy i spowiednik margrabiego Georga Friedricha. Ponieważ jednak margrabiemu powierzono administrację Księstwa Pruskiego w zastępstwie za jego chorego psychicznie kuzyna księcia Albrechta Fryderyka, Artomedes wraz ze swoim władcą w 1578 roku wyjechał do Prus. Rok później został pastorem w katedrze w Królewcu, a na uniwersytecie Albertynie otrzymał katedrę Wydziału Teologicznego. Artomedes reprezentował umiarkowany teologiczny punkt widzenia na reformację, więc nie był zaangażowany w teologiczne spory swoich czasów. Kultywował poezję duchową i sztukę głoszenia kazań zgodnie z zasadami humanistycznej retoryki. Dzięki licznym opublikowanym wierszom i kazaniom już za życia został ogłoszony poetą.

W XVII wieku działał ostatni z wielkich teologów reformacji - Johann Philipp Pfeiffer (1645-1695), (Norymberga - Królewiec - Lidzbark Warmiński - Dobre Miasto) (AKZO; Hoche 1887: 639-641). Przyszedł na świat w Norymberdze w 1645 roku. Był synem cesarskiego notariusza i sekretarza. Uczęszczał do szkoły św. Wawrzyńca, później gimnazjum, dopóki nie zapisał się na uniwersytet w Altdorf w 1663 roku, aby studiować teologię. Dwa lata później udał się na uniwersytet w Królewcu i tam kontynuował naukę. Następnie obronił doktorat z filozofii i rozpoczął wykłady. Wielki elektor Fryderyk Wilhelm mianował go w 1671 roku profesorem języka greckiego. Otrzymał polecenie m.in. tworzenia biblioteki zamkowej. W tych latach powstała jego główna praca dotycząca greckich antyków. W 1685 roku uzyskał doktorat z teologii i nominację na 
kaznodzieję sądowego. Po śmierci żony wzmocniła się u niego skłonność do katolicyzmu. Wywołało to pewne niezadowolenie wśród mieszkańców Królewca, dlatego Pfeiffer został zawieszony w 1694 roku z funkcji kaznodziei, profesora i bibliotekarza, a wkrótce całkowicie zwolniony z tych stanowisk. Wykorzystał wówczas wcześniejsze zaproszenie biskupa warmińskiego Jana Stanisława Zbąskiego, udał się do Lidzbarka Warmińskiego i 25 lipca 1694 roku przeszedł na katolicyzm. Następnie otrzymał od biskupa kanonię dobromiejską, gdzie zmarł w 1695 roku. Został jednak pochowany w kościele parafialnym w Lidzbarku Warmińskim.

\section{Związki naukowo-kulturalne w XIX i początkach XX wieku}

Niezwykle ciekawą postacią, zupełnie nie znaną na Warmii i Mazurach, jest Ernst Theodor Amadeus Hoffmann (1776-1822), poeta, pisarz epoki romantyzmu, prawnik, kompozytor, rysownik i karykaturzysta (Królewiec - Bamberg) (Braun 2004). Był trzecim dzieckiem adwokata i literata z Królewca, gdzie ukończył gimnazjum. W latach 1795-1797 odbywał praktykę w sądzie w Głogowie. W mieście tym przyozdobił freskami jedną z kaplic kościoła pojezuickiego. Od roku 1800 pracował jako asesor rządowy w Poznaniu. Znając język polski i mając liczne kontakty z Polakami, miał pozytywny stosunek do insurekcji kościuszkowskiej i nie był zwolennikiem rozbiorów Polski. Za rysowanie karykatur przedstawiających wyższych urzędników i oficerów został przeniesiony w 1802 roku do Płocka, a potem do Warszawy. Po wojnie prusko-francuskiej, w 1808 roku został dyrektorem muzycznym teatru w Bambergu, następnie w Dreźnie i Lipsku. W roku 1816 powrócił do służby sądowej w Berlinie.

Od młodości z zamiłowaniem poświęcał się muzyce, komponował liczne utwory muzyczne (kościelne, operowe i orkiestrowe). Opierał się na tradycji Mozarta oraz Beethovena. Jego muzyka należy jednak do następnej epoki - romantyzmu, a Hoffmann jest uważany za twórcę pierwszej opery romantycznej (Undine). Od kilkunastu lat w Poznaniu co roku odbywa się Festiwal Hoffmannowski, organizowany przez Teatr Wielki im. Stanisława Moniuszki. Napisał też wiele tekstów literackich: poezje, opowiadania, bajki i powieści fantastyczne. Najsłynniejszym dziełem jest fantastyczna baśń Dziadek do orzechów, przetłumaczona na wiele języków, na podstawie której Piotr Czajkowski skomponował balet. Jako rysownik i malarz odznaczył się w grotesce i karykaturze, godne uwagi są również jego obrazy (autoportrety) i projekty dekoracji teatralnych.

Kolejny okres wzmożonych kontaktów między Frankonią/Bawarią a ziemiami pruskimi nastąpił wraz z rozwojem nauki. Jednym z naukowców był botanik, pierwszy dyrektor Ogrodu Botanicznego w Królewcu - August Friedrich Schweigger (1783-1821), (Erlangen - Królewiec) (AKZO; Wunschmann 1891: 
332-333). Urodził się 8 września 1783 roku w Erlangen. Pochodził ze słynnej rodziny uczonych i ukończył wszechstronną edukację ze swoim bratem Christophem, fizykiem, który później nauczał w Halle. Po ukończeniu szkoły średniej rozpoczął w 1800 roku studia akademickie z medycyny, zoologii i botaniki. W 1804 roku uzyskał doktorat i wyjechał do Berlina, gdzie został objęty patronatem ministra Steina von Altenstein. To dało mu środki na naukową podróż do Paryża, gdzie przebywał trzy lata. W tym czasie pracował w lokalnych muzeach i stacjach naukowych oraz nawiązał kontakty $\mathrm{z}$ francuskimi uczonymi. W 1809 roku Schweigger przybył do Prus Wschodnich na wezwanie Uniwersytetu w Królewcu, aby przyjąć profesurę botaniki. W tym samym roku król niemiecki przeznaczył nieruchomość między ulicami Bessel a Butterbergstraße na założenie ogrodu botanicznego. Wilhelm von Humboldt, kierownik Sekcji Edukacji i Nauczania w pruskim Ministerstwie Spraw Wewnętrznych, mianował Schweiggera na pierwszego dyrektora tego obiektu. Miał stać się on jednym z najpiękniejszych ogrodów botanicznych w Niemczech. Jako dyrektor Ogrodu Botanicznego i nauczania akademickiego, Schweigger odbywał liczne podróże naukowe. Jedna z nich doprowadziła go w 1821 roku na Sycylię, gdzie jako 37-letni człowiek zginął w Agrigento z rąk miejscowego przewodnika. Jego koledzy z Królewca, chcąc uczcić przedwczesną śmierć uczonego, postanowili wznieść pomnik w jego miejscu pracy, który stanął w 1824 roku. W wyniku II wojny światowej Ogród Botaniczny został całkowicie zniszczony, a wraz z nim pomnik Schweiggera.

Innym naukowcem, zwanym ojcem chirurgii plastycznej, był Johann Friedrich Dieffenbach (1792-1847), (Królewiec - Würzburg) (AKZO). Urodził się w Królewcu i w wieku 20 lat rozpoczął studia teologiczne na uniwersytecie w Rostocku. Wojna przerwała jego edukację, ponieważ zgłosił się na ochotnika do armii. Po strasznych doświadczeniach wojny francusko-pruskiej (1812-1813) postanowił poświęcić się medycynie. W 1816 roku zapisał się na królewiecką Albertynę, ale niebawem został współzałożycielem nielegalnego bractwa studenckiego i policja wyeksmitowała go z miasta. Kontynuował studia w Bonn, Paryżu, a zwłaszcza we frankońskim mieście Würzburg. Tam uzyskał doktorat w 1822 roku i rozpoczął życie zawodowe. Najpierw zajmował się pracą nad przeszczepem i chirurgią plastyczną, a następnie rozwojem tenotomii (przecięcie ścięgien). W tym celu napisał liczne prace naukowe, które zostały opublikowane w kilku językach i tym samym ugruntowały jego międzynarodową sławę. Uważany jest zatem za ojca chirurgii plastycznej. Po ukończeniu doktoratu w Würzburgu przeniósł się w 1824 roku do Berlina, gdzie zdał egzamin państwowy, a następnie odbył praktykę lekarską. W swoim życiu zawodowym doszedł do stanowiska dyrektora w szpitalu królewieckim (ryc. 3). 


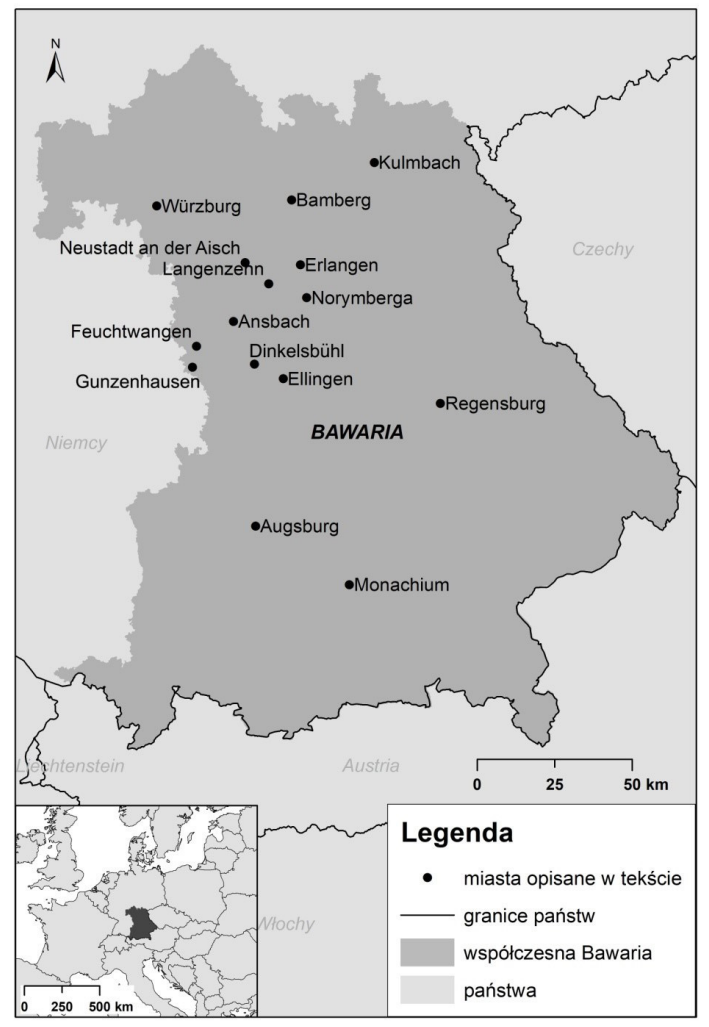

Ryc. 3. Współczesna Bawaria

Źródło: oprac. Ł. Musiaka

Kolejnym badaczem, związanym zarówno z Bawarią, jak i Prusami Wschodnimi, był agronom Gustav Friedrich Wilhelm Fleischmann (1837-1920), (Norymberga - Królewiec) (AKZO). Fleischmann ukończył humanistyczne gimnazjum w Norymberdze, od 1856 roku studiował matematykę i fizykę w Würzburgu, Erlangen i Monachium, a doktorat otrzymał w 1861 roku w Tybindze. Za radą swojego nauczyciela, Justusa von Liebiga, skierował zainteresowania naukowe na agrochemię. W latach 1864-1872 wykładał w szkołach w Memmingen i Lindau nad Jeziorem Bodeńskim, a jednocześnie prowadził rolnicze stacje doświadczalne. W Raden w Meklemburgii założył pierwszą stację doświadczalną w dziedzinie mleczarstwa, tam też otrzymał nominację na profesora Wielkiego Księstwa Meklemburskiego. W 1886 roku Fleischmann przybył na uniwersytet w Królewcu i jako profesor zwyczajny objął kierownictwo Instytutu Rolnictwa. W 1894 roku był rektorem Albertyny, a koło Labiau (pol. Labiawa, ros. Pollesk) założył stację doświadczalną w rolnictwie i szkołę hodowli bydła mlecznego. Dwa lata później przeniósł się na uniwersytet w Getyndze jako profesor rolnictwa. Wilhelm Fleischmann był jednym z pierwszych naukowców, który dostrzegł znaczenie podstawowych badań naukowych w hodowli bydła mlecznego. Był uważany za wiodącego eksperta w dziedzinie mleka w Niemczech i można go uważać za 
twórcę mleczarstwa. Opracował między innymi nowe metody analizy do obliczania suchej masy mleka, uzyskał nowy wgląd w skład chemiczny mleka i procesy bakteriologiczne związane z wytwarzaniem produktów mlecznych.

Najbardziej docenionymi badaczami są laureaci Nagrody Nobla wywodzący się z Prus Wschodnich. Wśród nich wymienić możemy Emila Behringa (ur. w Ławicach pod Iławą) oraz Fritza Lipmanna (ur. w Królewcu), którzy otrzymali nagrody z fizjologii lub medycyny, pierwszy w 1901 roku, drugi w 1953 roku. Jednak tylko jeden z nich Wilhelm Carl Werner Wien (1864-1928), laureat Nagrody Nobla z fizyki, był związany później z Bawarią (Kętrzyn - Królewiec - Würzburg) (AKZO). Urodził się 13 stycznia 1864 roku w Gaffken pod Fischhausen (ros. Parusnoje k. Primorska), jako syn rolnika, imigranta z Meklemburgii. Ojciec sprzedał lokalną własność i nabył niewielką posiadłość w Drachenstein (pol. Smokowo) koło Kętrzyna. Tam Wilhelm spędził młodość, najpierw uczęszczał do wiejskiej szkoły, a później przeniósł się do gimnazjum w Kętrzynie. Ponieważ jego osiągnięcia były raczej umiarkowane, opuścił szkołę i był dalej kształcony przez prywatnych nauczycieli. Następnie uczęszczał do liceum na Starym Mieście w Królewcu, gdzie rozwinął swoje zainteresowania matematyką i naukami przyrodniczymi. Wien rozpoczął w 1882 roku studia matematyczne w Getyndze, a następnie z fizyki w Berlinie. W ciągu 10 lat ukończył doktorat i habilitował się na Uniwersytecie Friedricha Wilhelma w Berlinie. Później pracował na uniwersytetach w Akwizgranie i Giessen, aż w 1900 roku przeniósł się na uniwersytet w Würzburgu. W swoich naukowych ustaleniach twierdził, że wszystkie procesy fizyczne mają charakter elektromagnetyczny i że masę ciała można obliczyć całkowicie na podstawie jego energii elektromagnetycznej. W czasie pobytu w Würzburgu otrzymał Nagrodę Nobla w dziedzinie fizyki (1911 r.) za wieloletnie badania naukowe nad promieniowaniem cieplnym. W ten sposób Wien położył podwaliny pod teorię kwantową Plancka i specjalną teorię względności Einsteina. W latach 1913-1914 był rektorem Uniwersytetu w Würzburgu. Od 1920 roku wykładał na uniwersytecie w Monachium i był jego rektorem w latach 1925-1926. Zajmował także prestiżowe stanowisko przewodniczącego Niemieckiego Towarzystwa Fizycznego i Rady Muzeum Niemieckiego w Monachium.

\section{Trudny wiek XX}

Pod koniec II wojny światowej, w 1945 roku, bawarscy żołnierze 7 monachijskiej Dywizji Piechoty i 4 Dywizji Pancernej z Würzburgu i Bambergu, pomagali w ewakuacji z Prus Wschodnich dziesięciu tysięcy uciekających kobiet, dzieci, mężczyzn i rannych żołnierzy. Pamięć o ich poświęceniu przetrwała dzięei uciekinierom i przesiedleńcom, którzy znaleźli swoje miejsce w Bawarii. 
Nie można zapominać, że region ten również ucierpiał w wyniku bombardowań aliantów w ostatniej fazie wojny. 75\% miast bawarskich uległo częściowemu zniszczeniu, a całkowitemu 14,8\% z nich. Pod koniec 1945 roku Bawaria liczyła 6,5 miliona ludności rodzimej oraz 1,5 miliona osób przesiedlonych i cudzoziemców, nie uwzględniając amerykańskich wojsk okupacyjnych (Deportation... 1987: 24). Według pochodzenia, w Bawarii znalazło się 44\% przesiedleńców z Sudetów, 22\% ze Śląska, i 15\% ze środkowych Niemiec (późniejsza NRD). $7 \%$ uchodźców, przesiedleńców lub wypędzonych pochodziło z południowo-wschodniej Europy, 4\% z Prus Wschodnich i Zachodnich oraz 8\% z innych terytoriów przedwojennych Niemiec. Później liczba uchodźców z Prus Wschodnich jeszcze wzrosła ze względu na wewnętrzną migrację. Katolicy przenosili się do Bawarii, w północnych landach niemieckich pozostawali protestanci. Według spisu ludności mieszkańców z 27 maja 1970 roku w Republice Federalnej Niemiec mieszkało 11,2 miliona osób wysiedlonych ( $\mathrm{w}$ tym w Bawarii nieco ponad $2 \mathrm{mi}$ liony) i około 3,6 miliona uchodźców z NRD (z tego w Bawarii 370000). Daje to udział ponad $25 \%$ uchodźców i wysiedlonych w całkowitej populacji Niemiec, natomiast w Bawarii było to $24 \%$ w stosunku do ludności landu (Ibidem, s. 23).

Aby utrzymywać więzi kulturowe, uchodźcy i przesiedleńcy organizowali się we wspólnoty krajowe, zwane w Polsce ziomkostwami. Ważna też była integracja kulturalna, ale rozwijała się ona bardzo powoli. Dopiero po zakończeniu problemów mieszkaniowych, finansowych i społecznych, można było na szerszą skalę zainwestować w promocję kultury wschodnioniemieckiej. Podstawy do tego dał już w 1953 roku ustawodawca federalny, który w paragrafie 96. Federalnej Ustawy o Uchodźcach i Wypędzonych uznał utrzymanie, zachowanie i przekazywanie dziedzictwa kulturowego niemieckich obszarów przesiedleńczych za obowiązek krajowy. Wynikało to z deklaracji, że dziedzictwo kulturowe niemieckich terytoriów przesiedleńczych jest wspólnym elementem niemieckiej kultury i niemieckiego życia intelektualnego. Wobec tego powinno być docenione, zachowane i przekazane następnemu pokoleniu przez wszystkich Niemców (nie tylko przesiedleńców) (Ibidem, s. 27).

W latach 70. XX wieku wspólnoty byłych mieszkańców Prus Wschodnich działały dość sprawnie i zgromadziły wiele materiałów (dokumentów, zdjęć, wspomnień) na temat swoich miejscowości czy powiatów. Reprezentowały one prawie cały obszar Niemiec Zachodnich, tj. Badenię-Wirtembergię, Bawarię, Berlin, Bremę, Hamburg, Hesję, Dolną Saksonię, Nadrenię Północną-Westfalię, Nadrenię-Palatynat, Saarę, Szlezwik-Holsztyn. W 1971 roku w Monachium założono Fundację Prus Wschodnich i Zachodnich, a w 1977 roku Ziomkostwo Wschodniopruskie zaapelowało do Federalnego Ministerstwa Spraw Wewnętrznych w Bonn, by zorganizować centralny punkt zbiórki i gromadzenia dziedzictwa kulturowego Prus Wschodnich. Idea ta nabrała realnych kształtów po oficjalnym przejęciu 16 września 1978 roku przez Wolne Państwo Bawarskie patronatu nad dawnymi mieszkańcami Prus Wschodnich (AKZO). 


\section{Wspólczesne postrzeganie dziedzictwa ziem pruskich na przykładzie Centrum Kultury Prus Wschodnich w Ellingen}

Wielowiekowe związki historyczne i kulturowe oraz żywe wpływy wschodniopruskie po II wojnie światowej, dzięki pamięci utrzymywanej przez przesiedleńców, spowodowały umiejscowienie Centrum Kultury Prus Wschodnich właśnie w Bawarii. Jako lokalizacja dla tej instytucji został wybrany dawny pałac zakonu krzyżackiego w Ellingen we Frankonii. Rezydencja była od XIII do XIX wieku siedzibą komtura krajowego, a od drugiej połowy XIV wieku także stolicą Baliwatu Frankońskiego Zakonu Niemieckiego. Pałac w Ellingen, należący od 1815 roku do książąt von Wrede, jest uważany za jeden z najważniejszych pałaców krzyżackich w XVIII wieku. W 1939 roku ten ogromny kompleks rezydencji został przejęty przez państwo bawarskie i przekazany Bawarskiemu Państwowemu Zarządowi Zamków, Pałaców, Ogrodów i Jezior .

Po II wojnie światowej przez wiele lat pałac w Ellingen stał pusty i nie wiadomo było na co przeznaczyć tak wielki obiekt w małym miasteczku, liczącym niewiele ponad 3 tys. mieszkańców. Takich zabytkowych obiektów na terenie Bawarii było więcej, wobec czego rząd bawarski postanowił w 1954 roku włączyć zamek Ellingen w struktury Bawarskiego Zarządu Zamków, Pałaców, Ogrodów i Jezior (Crailsheim 1981). Dwa lata później otworzono nowy pokój muzealny całkowicie poświęcony historii Zakonu Niemieckiego i komtura krajowego w Ellingen, w którym zgromadzono dzieła sztuki i pamiątki z czasów Zakonu rozrzucone do tej pory w różnych miejscach Niemiec. Tym samym, choć tylko w formie muzealnej, tradycje niemieckiego Baliwatu Frankonii zostały zachowane (Bachmann 1976: 31). Liczba odwiedzających rezydencję Ellingen do lat 80. XX wieku wzrosła ponad trzykrotnie, co było dowodem rosnącej świadomości historycznej mieszkańców. Otwarcie Centrum Kultury Prus Wschodnich w zachodnim skrzydle pałacu dodatkowo uatrakcyjniło ofertę muzealną.

Było to możliwe dzięki dobrej atmosferze politycznej, która nastąpiła na początku lat 70. XX wieku wraz z ociepleniem stosunków polsko-niemieckich, a także objęciem w 1978 roku patronatu sponsorskiego nad ludnością przesiedloną z byłych Prus Wschodnich przez Wolne Państwo Bawarskie. Przeznaczenie znacznych sum pieniężnych na remont zachodniego skrzydła pałacu w Ellingen doprowadziło 25 września 1981 roku do otwarcia Kulturzentrum Ostpreussen z archiwum i muzeum (Beredtes Zeugnis... 1981; Hennig 1981; Ostpreußen... 1981; Ostpreußen-Museum... 1981; Pirkl 1981; Pflege alter Kulturgüter 1981).

Obecnie Centrum Kultury posiada unikatowe i rzadkie eksponaty z obszaru między dolną Wisłą a Niemnem. Nowoczesny system oprowadzania audio

\footnotetext{
${ }^{4}$ Czasami thumaczonej jako Administracja Zamków, Ogrodów i Jezior, https://www. schloesser.bayern.de/ (dostęp: 20.09.2019).
} 
dostarcza bogatych w informacje wyjaśnień. Oprócz archiwum i biblioteki, znajduje się tu również część muzealna poświęcona studiom regionalnym oraz historii i kulturze Prus Wschodnich. Wybrane tematy to m.in. bursztynowy gabinet, pokój obywatela z Królewca, Prusy Wschodnie w kartografii, historyczna broń myśliwska, majolika kadyńska, historia i kultura przesiedleńców z Salzburga, kultura ludowa, katolicka Warmia, galeria zdjęć i inne. Co roku Centrum Kultury przygotowuje kilka wystaw specjalnych i gabinetowych - również w ramach transgranicznej współpracy kulturalnej z instytucjami polskimi, rosyjskimi i litewskimi. Dwujęzyczne wystawy stałe poświęcone historii poszczególnych miast, które zostały zainstalowane w ostatnich latach na Warmii i Mazurach wzbudzają duże zainteresowanie.

Warto szerzej zastanowić się nad różnicami w postrzeganiu dziedzictwa ziem pruskich przez Centrum Kultury Prus Wschodnich w Ellingen po stronie niemieckiej, a Muzeum Warmii i Mazur w Olsztynie wraz z oddziałami po stronie polskiej. W Niemczech istnieje kilka toposów charakteryzujących ziemie pruskie. $\mathrm{Z}$ zakresu przyrody i geografii to przede wszystkim bursztyn, zarówno w postaci naturalnej, jak i dzieł sztuki. Na Warmii i Mazurach bursztyn nie jest prezentowany jako dziedzictwo kulturowe, centrum badań i kultury bursztynu znajduje się w Gdańsku oraz w Kaliningradzie. Drugim ważnym elementem geografii i przyrody jest Puszcza Romincka i król zwierząt - łoś, a także koń ze stadniny w Trakenach (dziś Obwód Kaliningradzki). Na Warmii i Mazurach zwierzętami najczęściej prezentowanym są: jeleń, wilk i dzik. Obecnie łoś uważany jest nawet za szkodnika. Nie pokazuje się też koni trakeńskich, jako spuścizny poniemieckiej.

W Niemczech z nostalgią przedstawiana jest Mierzeja Kurońska (podzielona dziś między Rosję a Litwę) z piaszczystymi wydmami oraz charakterystycznymi dla każdej rybackiej osady proporcami. Z tym łączą się także elementy kultury i dzieł artystycznych. Na mierzei znana była w okresie międzywojennym kolonia artystów w Nidzie, stąd w Centrum Kultury prezentuje się prace Lovisa Corintha, Carla Knaufa czy Thomasa Manna. Na wystawie stoją rzeźby autorstwa Edith Sadden-Guja oraz Hermanna Bracherta.

Wspólne dla niemieckiej i polskiej kultury są postaci: Mikołaja Kopernika, Johanna Gotfrieda Herdera, Ernsta Wiecherta. Jednak więcej nas dzieli. W Centrum Kultury przedstawiani są ponadto: Immanuel Kant, Friedrich Wilhelm Bessel, Simon Dach, Johan Georg Hamann, Ernst Theodor Amadeus Hoffmann, Wilhelm Wien, Eduard von Simson, Hermann Sudermann, Elisabeth Boehm, Käthe Kolwitz, Agnes Miegel, Johannes Bobrowski i inni. Natomiast na Warmii i Mazurach prezentowane są nieznane w Niemczech postaci: bp Stanisław Hozjusz, bp Ignacy Krasicki, Gustaw Gizewiusz, Krzysztof Mrongowiusz, Wojciech Kętrzyński, Karol Małłek, Emilia Sukertowa-Biedrawina, Hieronim Skurpski, Maria Zientara-Malewska i inni. 
Zaciekawiło mnie, dlaczego w Centrum Kultury Prus Wschodnich nie prezentuje się np. laureata Nagrody Nobla Emila von Behringa, urodzonego w Ławicach pod Iławą (nagroda w $1901 \mathrm{r}$.), ani migrantów religijnych z Rosji - filiponów, zwanych też starowiercami, którzy zostali zaproszeni do Prus w 1825 roku, a w prezentacji dialektów nie pojawia się ani gwara warmińska, ani mazurska, a jedynie plattdeutsch, jako dialekt wschodniopruski. Dużo uwagi poświęca się za to Akademii Królewieckiej, w przeciwieństwie do Warmii i Mazur, gdzie nie ma o niej w ogóle mowy.

Jeżeli chodzi o historię, to na Warmii i Mazurach dużo więcej uwagi przywiązuje się do plemion pruskich, ich walki z Krzyżakami oraz oczywiście do najsłynniejszej bitwy średniowiecza - bitwy pod Grunwaldem. Także po stronie niemieckiej nie pomija się tematu bitwy, jednak nie stoi ona na pierwszym planie. Godną uwagi w pałacu Ellingen jest wielka makieta przedstawiająca układ wojsk w bitwie pod Grunwaldem w 1410 roku. Odrębną salę i prezentację multimedialną poświęcono jednak drugiej bitwie grunwaldzkiej, tj. bitwie pod Tannenbergiem z 1914 roku, zwycięskiej dla armii niemieckiej. Dużą wagę przywiązuje się do pamiątek po marszałku Paulu von Hindenburgu. Na Warmii i Mazurach nie ma oddzielnej wystawy stałej poświęconej tej bitwie, ale kilka lat temu na Mazurach w Olsztynku otwarto multimedialną wystawę stałą poświęconą jeńcom Stalagu I B Hohenstein. W byłych Prusach Wschodnich istniały też obozy koncentracyjne w Stutthof (dziś w woj. pomorskim) oraz w Działdowie, o żadnym z nich nie wspomina się w Kulturzentrum Ostpreussen.

Temat porównania prezentacji Prus Wschodnich po stronie niemieckiej i polskiej został tu jedynie zasygnalizowany, bowiem wymaga pogłębionej analizy wystaw muzealnych i sposobów prezentacji w muzeum w Olsztynie i jego oddziałach w terenie, a także muzeach Obwodu Kaliningradzkiego i Okręgu Kłajpedy. Warta odnotowania jest jednak podstawowa różnica: w Niemczech Prusy Wschodnie postrzega się jako jeden spójny region, zaś na Warmii i Mazurach prezentuje się w zasadzie tylko południową cześć Prus Wschodnich, podobnie jak w Kaliningradzie - część północną. Ciekawe są także wnioski z rozważań na temat Krajowego Muzeum Prus Wschodnich w Lüneburgu (Lewandowska 2020: 367-385). Podjęcie takiego tematu byłoby wskazane chociażby ze względu na wyjaśnienie polityki historycznej odnoszącej się do Prus Wschodnich, jak też sposobów kładzenia akcentów na prezentację historii i dóbr kultury z tego obszaru. Efekty tych badań byłyby ciekawe dla wszystkich czterech zainteresowanych krajów: Niemiec, Polski, Rosji i Litwy. 


\section{Literatura}

Arnold U., Seis H. (tekst), Freyberg W. (red.), 2016, 800 Jahre Deutscher Orden in seiner Residenz Ellingen, Kulturzentrum Ostpreussen, Ellingen.

Bachmann E., 1976, Rezidenz Ellingen, Bayerische Verwaltung der Staatlichen Schlösser, Gärten und Seen, München.

Beredtes Zeugnis tiefer Verbundenheit, 1981, „Das Ostpreussenblatt”, 41, z dnia 10 X 1981.

Braun P., 2004, E.T.A. Hoffmann. Dichter, Zeichner, Musiker. Biographie, Artemis und Winkler, Düsseldorf.

Crailsheim H.-J., 1981, Würdige Heimstatt gefunden, „Das Osptreussenblatt”, 41, z dnia 10 X 1981.

Deportation, Flucht und Vertreibung. Ein Rückblick nach 40 Jahren, 1987, Bayerisches Staatsministerium für Arbeit und Sozialordnung, München.

Dudo J., 1995, Gospodarcze aspekty środowiska naturalnego w Obwodzie Kaliningradzkim, Wydawnictwo Ośrodka Badań Naukowych, Olsztyn.

Hennig O., 1981, Ostpreußen muß leben und überlebe, „Das Osptreußenblatt”, 41, z dnia $10 \times 1981$

Kłopotowski A., 2018, Monachium i Bawaria, Wydawnictwo Helion, Gliwice.

Kulturzentrum Ostpreussen in Schloss Ellingen, 1981, „The Ostpreussenblatt”, 41, z dnia 10 X 1981.

Lewandowska I., 2009, Warmia and Masuria - Kaliningrad Oblast - Klaipèda Region. Three regions instead of one (East Prussia), [w:] Sobczyński M. (red.), Historical regions divided by the borders. General problems and regional issue, „Region and Regionalism", 9(1), Wydawnictwo Uniwersytetu Łódzkiego, Łódź-Opole.

Lewandowska I., 2020, Ostpreussisches Landesmuseum w Lüneburgu - historia, zbiory, działalność, „Przegląd Zachodni”, 2: 367-385.

Małłek J., 1987, Dwie części Prus. Studia z dziejów Prus Książęcych i Prus Królewskich w XVI i XVII wieku, Ośrodek Badań Naukowych, Olsztyn.

McLachlan G., 1998, Niemcy. Część południowa. Bawaria, Badenia-Wirtembergia, Pascal, Bielsko-Biała.

Ostpreußen im Deutschordensschloss, 1981, „Weissenburger Zeitung”, 225, z dnia 29 IX 1981.

Ostpreußen-Museum im Schloss Ellingen, 1981, „Westpreussischer Tageblatt”, z dnia 26-27 IX 1981.

Pflege alter Kulturgüter, 1981, „Nürnberger Nachrichten”, z dnia 26 IX 1981.

Pirkl F., 1981, Ein Zeichen des Dankes für Einsatz und Leistung, „Das Osptreußenblatt”, 41, z dnia 10 X 1981.

Piuziński P., 2003, Poczet wielkich mistrzów krzyżackich, Wydawnictwo Arenga, Gdańsk. 
Sakson A., 2011, Od Kłajpedy do Olsztyna. Współcześni mieszkańcy bytych Prus Wschodnich: Kraj Kłajpedzki, Obwód Kaliningradzki, Warmia i Mazury, Wydawnictwo Instytutu Zachodniego, Poznań.

Seebass G., 1967, Das Reformatorische Werk des Andreas Osiander, Selbstverlag des Vereins für Bayerische Kirchengeschichte, Nürnberg.

Stupperich R., 1973, Osiander in Preussen 1549-1552, De Gruyter, Berlin-New York.

\title{
Źródla
}

AKZO - Archiwum Kulturzentrum Ostpreussen (Centrum Kultury Prus Wschodnich) w Ellingen, Materiały do wystawy: ,Frankonia w Prusach. Prusacy we Frankonii. Historyczne i kulturowe interakcje w ciągu ośmiu wieków”; Przegląd grup regionalnych Wspólnoty Krajowej Prus Wschodnich; dokumenty różne.

Bessau M., 1955, Blasius Berwart, [w:] Neue Deutsche Biographie, Berlin, https:/www. deutsche-biographie.de/gnd130562769.html\#ndbcontent (dostęp: 15.12.2019).

Gause F., 1953, Artomedes Sebastian, [w:] Neue Deutsche Biographie, Berlin, https:// www.deutsche-biographie.de/gnd124821944.html\#ndbcontent (dostęp: 15.12.2019).

Hoche R., 1887, Johann Philipp Pfeiffer, [w:] Allgemeine Deutsche Bibliographie, https:// www.deutsche-biographie.de/sfz95290.html (dostęp: 15.12.2019).

Wunschmann E., 1891, August Friedrich Schweigger, [w:] Allgemeine Deutsche Biographie, publisched by „Historical Commission at the Bavarian Academy of Sciences”, 33, https://de.wikisource.org/wiki/ADB:Schweigger,_August_Friedrich (dostęp: 15.12.2019).

\section{Netografia}

http://archwarmia.pl/instytucje/muzeum-archidiecezji-warminskiej/ (dostęp: 10.11.2019). https://www.schloesser.bayern.de/ (dostęp: 20.09.2019).

\section{Between Bavaria and East Prussia. Geographical, historical and cultural connections and contemporary perception of the heritage of the Prussian lands}

\begin{abstract}
Today's Bavaria, the richest land in modern Germany, consists of the historical lands of Franconia and Swabia. East Prussia no longer exists, but the memory of it is still alive among its former residents, who were displaced or left intentionally after World War II. In the chapter I will show similarities and differences in the geography and the historical and cultural relationships over the centuries. In the second part of the chapter I will focus on the heritage of the Prussian lands, as presented by the Center of East Prussia Culture in Ellingen, housed in the former palace of the German Order (a.k.a. the Teutonic Knights) in the central part of Bavaria. The studies conducted during my six-week-long scientific internship at Ellingen have enriched my personal observations and allowed me to write the chapter.
\end{abstract}


Keywords: Bavaria, East Prussia, cultural heritage, Cultural Centrum of East Prussia.

Dr hab. Izabela Lewandowska, prof. UWM

Uniwersytet Warmińsko-Mazurski w Olsztynie

Wydział Humanistyczny

Instytut Historii

e-mail: iza.lewandowska@uwm.edu.pl

(D) https://orcid.org/0000-0003-0853-7913 